\title{
A millennial discharge summary
}

Paul Wicks imagines a discharge summary from the not too distant future

\section{Paul Wicks vice president of innovation}

PatientsLikeMe, Cambridge, MA 02141, USA

Disclosures: Paul Wicks is just barely a millennial, which he thinks entitles him to make fun of his own generation (and to just be entitled generally). No patients were trolled during the writing of this article.

Competing interests: I have read and understood BMJ policy on declaration of interests and declare that I have no competing interests.
Provenance and peer review: Commissioned; not externally peer reviewed.

Published by the BMJ Publishing Group Limited. For permission to use (where not already granted under a licence) please go to http://group.bmj.com/group/rights-licensing/ permissions 


\section{Figure}



